\title{
Early Exposure to Genistein Exerts Long-Lasting Effects on the Endocrine and Immune Systems in Rats
}

\author{
Sabra L. Klein, ${ }^{1}$ Amy B. Wisniewski, ${ }^{2}$ Aimee L. Marson, ${ }^{3}$ Gregory E. Glass, ${ }^{1}$ and John P. Gearhart ${ }^{4}$ \\ ${ }^{1}$ The W. Harry Feinstone Department of Molecular Microbiology and Immunology, The Johns Hopkins \\ Bloomberg School of Public Health, Baltimore, Maryland, USA \\ ${ }^{2}$ Department of Pediatrics, The Johns Hopkins School of Medicine, Baltimore, Maryland, USA \\ ${ }^{3}$ Department of Oncology, The Johns Hopkins School of Medicine, Baltimore, Maryland, USA \\ ${ }^{4}$ Department of Urology, The Johns Hopkins School of Medicine, Baltimore, Maryland, USA \\ Accepted September 26, 2002
}

\begin{abstract}
Background: Although the immunologic effects of endogenous and synthetic estrogens are well studied, few studies have examined the hormonal effects of phytoestrogens (i.e., plant-derived estrogens) on the immune system. The primary goal of this study was to compare the effects of perinatal exposure with life-long exposure to genistein, an estrogenic compound in soy, on the endocrine and immune system in adulthood.

Materials and Methods: Pregnant female rats were exposed to no, low ( $5 \mathrm{mg} / \mathrm{kg} \mathrm{diet})$, or high $(300 \mathrm{mg} / \mathrm{kg}$ diet $)$ genistein diets throughout gestation and lactation. At weaning, male offspring exposed to genistein perinatally were either switched to the genistein-free diet or remained on the genistein-dosed diets. At 70 days of age, immune organ masses, lymphocyte subpopulations, cytokine concentrations, and testosterone concentrations were assessed in male offspring.

Results: Data were analyzed based on the diets that males were exposed to during gestation and lactation because life-long exposure to genistein had no additional
\end{abstract}

effect on any of the dependent measures. Relative thymus masses were greater among males exposed to the high genistein diet than among males exposed to no genistein. Although the proportions of splenic and thymic $\mathrm{CD}^{+} \mathrm{T}$ cells were not altered by genistein, the percentages of $\mathrm{CD}^{+} \mathrm{CD}^{+}$thymocytes, $\mathrm{CD}^{+}$splenocytes, and total $\mathrm{T}$ cells in the spleen were higher and the percentages of $\mathrm{CD} 4^{-} \mathrm{CD} 8^{-}$thymocytes were lower among males exposed to genistein than among males not exposed to genistein. Synthesis of interferon- $\gamma($ IFN- $\gamma$ ) was marginally higher and testosterone concentrations were lower among genistein-exposed than genisteinfree males.

Discussion: These data illustrate that exposure to genistein during pregnancy and lactation exerts long-lasting effects on the endocrine and immune systems in adulthood. Whether exposure to phytoestrogens during early development affects responses to infectious or autoimmune diseases, as well as cancers, later in life requires investigation.

\section{Introduction}

Sex steroid hormones affect the immune system and susceptibility to disease (1). Generally, in nonpregnant animals, estrogens enhance immune function, reduce susceptibility to infectious diseases, and increase susceptibility to autoimmune diseases (1-3). Although estrogens can enhance both cell-mediated and humoral immune responses, there are reports of estrogens suppressing some cell-mediated immune responses $(4,5)$. Exposure of human natural killer (NK) cells to $17 \beta$-estradiol in vitro enhances NK cytotoxicity (6). Estrogens stimulate synthesis of proinflammatory cytokines (e.g., interleukin 1 (IL-1) and IL-6) suggesting that they are potent activators of

Address correspondence and reprint requests to: Sabra L. Klein, Department of Molecular Microbiology and Immunology, The Johns Hopkins Bloomberg School of Public Health, 615 North Wolfe Street, Baltimore, Maryland 21205. Phone: (410) 955-8898; fax: (410) 955-0105; e-mail: saklein@jhsph.edu. macrophages (2). Estrogens also affect the transcription and synthesis of helper T-cell type 1 (Th1)-related (e.g., interferon- $\gamma$ [IFN- $\gamma]$ and IL-2) and Th2-related (e.g., IL-4, IL-5, and IL-10) cytokines $(1-3,7)$. In contrast, androgens suppress several aspects of immune function and increase susceptibility to infection in males (1-3). For example, androgens can inhibit the production of proinflammatory cytokines by macrophages, reduce antibody production by B cells, and lower the numbers of $\mathrm{CD} 4^{+}$and $\mathrm{CD} 8^{+} \mathrm{T}$ cells in tissue and circulation (3). Although the effects of estrogens in females are well studied, there are few reports of the effects of estrogen exposure on immune function in males (7). Estrogen receptor- $\alpha(\operatorname{ER} \alpha)$ and $\operatorname{ER} \beta$ have been identified throughout the immune system and androgens can be aromatized intracellularly into estrogens in males $(8,9)$.

In addition to exposure to endogenous hormones, both humans and nonhuman animals are exposed to estrogenic chemicals in the environment 
$(10,11)$. These compounds, of both natural and synthetic origin, can either mimic or block the effects of endogenous hormones and are hypothesized to affect physiology and behavior (11-13). These chemicals bind to sex steroid receptors, but with a lower affinity than endogenous steroid hormones (14). In addition to effects on ligand receptors, estrogenic chemicals affect several intracellular molecules, including tyrosine kinase and glucose, indicating that environmental estrogens may exert their effects through cell signaling pathways $(15,16)$.

To date, most studies have focused on the effects of estrogenic pesticides and toxic substances on immune function (17-19); less attention has been paid to the effects of naturally occurring phytoestrogens on the immune system (20-22). With the increase in human consumption of phytoestrogens (e.g., via soy supplements, food products, and infant formulas), studies that address the physiologic consequences of phytoestrogen exposure are required (23). The effects of phytoestrogen exposure may vary depending on when during ontogeny exposure occurs (11). In vertebrates, sex steroid hormones affect sexspecific differentiation at two distinct times during development (24). During perinatal development (i.e., during gestation and lactation in rodents), sex steroids cause permanent changes in the development of the brain and peripheral organs, such as the gonads and thymus gland (organizational effects). After puberty, exposure to sex steroids transiently activates preexisting hormonal targets (activational effects).

Studies examining the effects of phytoestrogens, such as genistein (the estrogenic compound in soy), on the immune system typically expose animals to genistein after the critical period of sex differentiation. These studies reveal that exposure to genistein at puberty or during adulthood can affect the immune system. For example, adult exposure of intact female mice to the phytoestrogen genistein increases the development of pre-B cells in bone marrow, cytotoxic T-cell activity, NK cell activity, and lymphocyte proliferation in the spleen, and reduces tumor development $(25,26)$. In contrast, both adult and pubertal exposure of gonadectomized male and female mice to genistein reduces thymus size, lowers $\mathrm{CD} 4^{+} \mathrm{CD} 8^{-}$numbers in the thymus, increases thymocyte apoptosis, and decreases antibody responses against an innocuous antigen (22). The organizational effects of perinatal exposure to phytoestrogens on the immune system have not been reported.

Studies of the effects of phytoestrogens on reproduction illustrate that endocrine disrupting chemicals can have both organizational and activational effects in adulthood (27-29). Therefore, we designed our study to determine whether the effects of genistein on the immune and endocrine systems required exposure from gestation through adulthood (organizational and activational hypothesis) or if exposure during perinatal development was sufficient to alter endocrine and immune responses in adulthood (organizational hypothesis alone). Because the perinatal hormonal milieu is critical for normal physiologic development, we hypothesized that exposure to genistein solely during pregnancy and lactation may cause lasting immunologic alterations in adult male offspring. Perinatal exposure to estrogens enhances immune function in adult animals $(7,24)$; therefore, we speculated that exposure to genistein during gestation and lactation may increase immune responses in adult males. Because perinatal exposure to phytoestrogens reduces testosterone concentrations in males (30), we hypothesized that the immunoenhancing effects of genistein may indirectly be caused by reductions in testosterone concentrations.

\section{Materials and Methods Animals}

Adult (70-80 days of age) male $(n=12)$ and female $(n=12)$ Long Evans rats (Rattus norvegicus) were purchased from Charles River Laboratories (Raleigh, NC, USA) and housed individually in polypropylene cages. Animals were maintained on a constant LD 14:10 cycle with lights on at 0600 hr EST. Food and water were available ad libitum. The Johns Hopkins Animal Care and Use Committee (protocol \# RA01M227) approved all procedures described in this manuscript.

\section{Procedure}

Female rats were fed an irradiated soy- and alfalfafree diet (5K96, Purina Mills, St. Louis, MO, USA) that was supplemented with a high dose of genistein $(300 \mathrm{mg} / \mathrm{kg}$ feed), a low dose of genistein ( $5 \mathrm{mg} / \mathrm{kg}$ feed), or no genistein. These doses were based on previous studies that have examined the effects of genistein exposure during prenatal and early postnatal life on reproductive physiology and behavior (27-29). Genistein (Indofine Chemical Co., Somerville, NJ, USA) was mixed into the standard 5K96 feed by Purina Test Diets (Purina Mills). Genistein was selected as the endocrinedisrupting agent because it is the primary estrogenic isoflavonoid found in soy products, is structurally similar to endogenous estradiol, and binds to the ER, primarily ER $\beta$, with relatively high affinity as compared with other estrogenic agents $(14,31)$.

After 2 weeks on the specified diet, female rats were bred in the laboratory and gestational day 1 was based on the presence of a sperm plug. Females remained on the 5K96 diet supplemented with a high dose of genistein, a low dose of genistein, or no genistein through weaning (postnatal day [PND] 21). The daily mean consumption of genistein was recorded for each female. At PND 21, litters were culled and all male offspring were weaned and housed with same-sex siblings $(n=3$ per cage). At 
weaning, half of the genistein-exposed male offspring continued on the genistein dosed 5K96 diet, and the other half of the genistein-exposed male offspring were transferred to the standard 5K96 diet (a genistein free diet) for the duration of the study (27). All genistein-free males continued on the genistein-free diet. At 70 days of age, male rats were anesthetized with halothane $1: 3$ in mineral oil), blood samples were collected from the retroorbital sinus, animals were killed with an overdose of ketamine, and thymuses and spleens were collected and weighed. Splenic and thymic lymphocytes were isolated as described below.

Each experimental group consisted of 6-12 animals from four litters per treatment group $(n=12$ litters total). Only 1-3 animals per litter were included in each experimental group to reduce litter effects (32). From this data set, data on genistein consumption by dams and offspring as well as male offspring reproductive physiology and behavior were collected and are presented elsewhere (33). At birth the number of pups per litter, sex ratio, and pup birth weight were not affected by genistein exposure. Dams on the high genistein diet consumed approximately $7 \mathrm{mg}$ of genistein per day during pregnancy and approximately $18 \mathrm{mg}$ of genistein per day during lactation. Dams on the low genistein diet consumed about $0.13 \mathrm{mg}$ of genistein per day during pregnancy and about $0.28 \mathrm{mg}$ of genistein per day during lactation. For a 300 -g rat that consumed $25 \mathrm{~g}$ of food per day, these doses of genistein are comparable to consuming $0.42 \mathrm{mg} / \mathrm{kg} /$ day and $25 \mathrm{mg} / \mathrm{kg} /$ day for the low and high genistein diets, respectively. These quantities correspond with reported genistein, or other isoflavonoid, consumption in Western and Asian diets, respectively $(23,34)$.

\section{Lymphocyte Isolation}

Thymus and spleen tissues were each placed in the well of a 6-well plate with $3 \mathrm{ml}$ of sterile RPMI1640 medium (Mediatech Cellgro, Herndon, VA, USA), and lymphocytes were recovered by grinding the whole organ through a cell strainer (BD Falcon, Franklin Lakes, NJ, USA). Red blood cells (RBC) were lysed with RBC lysis buffer and cells were washed twice with phosphate-buffered saline (PBS). Lymphocytes were resuspended in PBS and lymphocyte counts and viability were determined using trypan blue exclusion (Sigma Chemicals, St. Louis, MO, USA).

\section{Fluorescence-Activated Cell Sorting}

Viable cells from the spleen and thymus were adjusted to $1 \times 10^{6}$ cells $/ \mathrm{ml}$, washed twice with fluorescence-activated cell sorting (FACS) buffer, and stained with fluorescein isothiocyanate-conjugated mouse anti-rat CD4, phycoerythrin (PE)-conjugated mouse anti-rat CD8, or PE-conjugated mouse antirat CD45R (BD Pharmingen, San Diego, CA, USA).
For FACS analysis, 40,000 events were collected on a FACScan (Becton Dickinson) and analyzed using CELLQuest software (Becton Dickinson).

\section{Cytokine Measurement}

Viable cells from the spleen and thymus were adjusted to $5 \times 10^{6}$ cells $/ \mathrm{ml}$ by dilution with culture medium (RPMI-1640/HEPES supplemented with $1 \%$ penicillin $[5000 \mathrm{U} / \mathrm{ml}] /$ streptomycin [5000 $\mu \mathrm{g} / \mathrm{ml}], 1 \%$ L-glutamine $[2 \mathrm{mM} / \mathrm{ml}], 0.1 \%$ 2-mercaptoethanol $\left[5 \times 10^{-2} \mathrm{M} / \mathrm{ml}\right]$, and $10 \%$ heat-inactivated fetal bovine serum) and were added to the wells of round-bottom 96-well tissue culture plates. Concanavalin A (Sigma) was added at final concentrations of $0.5 \mu \mathrm{g} /$ well for IFN- $\gamma$ and $3 \mu \mathrm{g} /$ well for IL-4. Plates were incubated at $37^{\circ} \mathrm{C}$ with $5 \% \mathrm{CO}_{2}$ for $48 \mathrm{hr}$ to assess IL-4 production and $72 \mathrm{hr}$ for IFN- $\gamma$ production. Mitogen concentrations and incubation times were based on previous data (35). At the end of the incubation, cell supernatant was removed from each well and stored at $-80{ }^{\circ} \mathrm{C}$. IL- 4 and IFN- $\gamma$ concentrations were assayed by enzyme-linked immunosorbent assay using the manufacturer's protocols for the OptEIA IL-4 and IFN- $\gamma$ kits (BD Pharmingen).

\section{Radioimmunoassays}

Plasma testosterone concentrations were assayed by radioimmunoassays (RIA) using the manufacturer's protocol (ICN Biochemicals, Inc., Carson, CA, USA). The testosterone assay is also highly specific; crossreaction with other steroids is $<0.1 \%$. Testosterone values were also determined in a single RIA, with a $4.4 \%$ intra-assay coefficient of variation.

\section{Statistical Analyses}

Despite our initial hypothesis (the organizational and activational hypothesis), animals exposed to genistein from gestation through adulthood did not differ from males exposed to genistein only during gestation and lactation on any of the dependent measures $(p>0.05)$. Because post-weaning diet changes (switching males from low or high genistein diets to genistein-free diets after weaning) did not affect immune or endocrine responses in adulthood, subsequent analyses were performed by collapsing across post-weaning treatment and comparing animals based on the perinatal diet (no, low, or high genistein exposure). Relative organ masses were calculated by dividing the organ mass by the body mass of each animal. Relative organ masses, lymphocyte subpopulations, cytokine responses, and hormone concentrations were analyzed with one-way ANOVAs. Significant outcomes were further analyzed using the Tukey method for pairwise multiple comparisons. Correlations were performed using Pearson's product-moment analyses. Differences among groups were considered statistically significant if $p<0.05$. 


\section{Results}

Thymus Mass Is Increased by Exposure to Genistein

Adult body mass was similar among male rats exposed to the high genistein $(383 \pm 14 \mathrm{~g})$, low genistein $(393 \pm 8 \mathrm{~g})$, and genistein-free $(411 \pm 14 \mathrm{~g})$ diets $(p>0.05)$. Relative spleen masses did not differ among males exposed to no, low, or high genistein diets $(p>0.05$; Fig. 1A). Relative thymus masses were heavier among males exposed to the high genistein diet compared with males exposed to the genistein-free or low genistein diets $(F(2,27)=$ 4.97, $p<0.05$; Fig. 1B).

\section{Subpopulations of T Cells Are Increased by Exposure to Genistein}

Using the total lymphocyte population for each organ, percentages of splenic $\mathrm{CD}^{+}{ }^{+} \mathrm{T}$ cells did not differ among males exposed to no, low, or high genistein diets $(p>0.05$; Table 1$)$. The proportion of
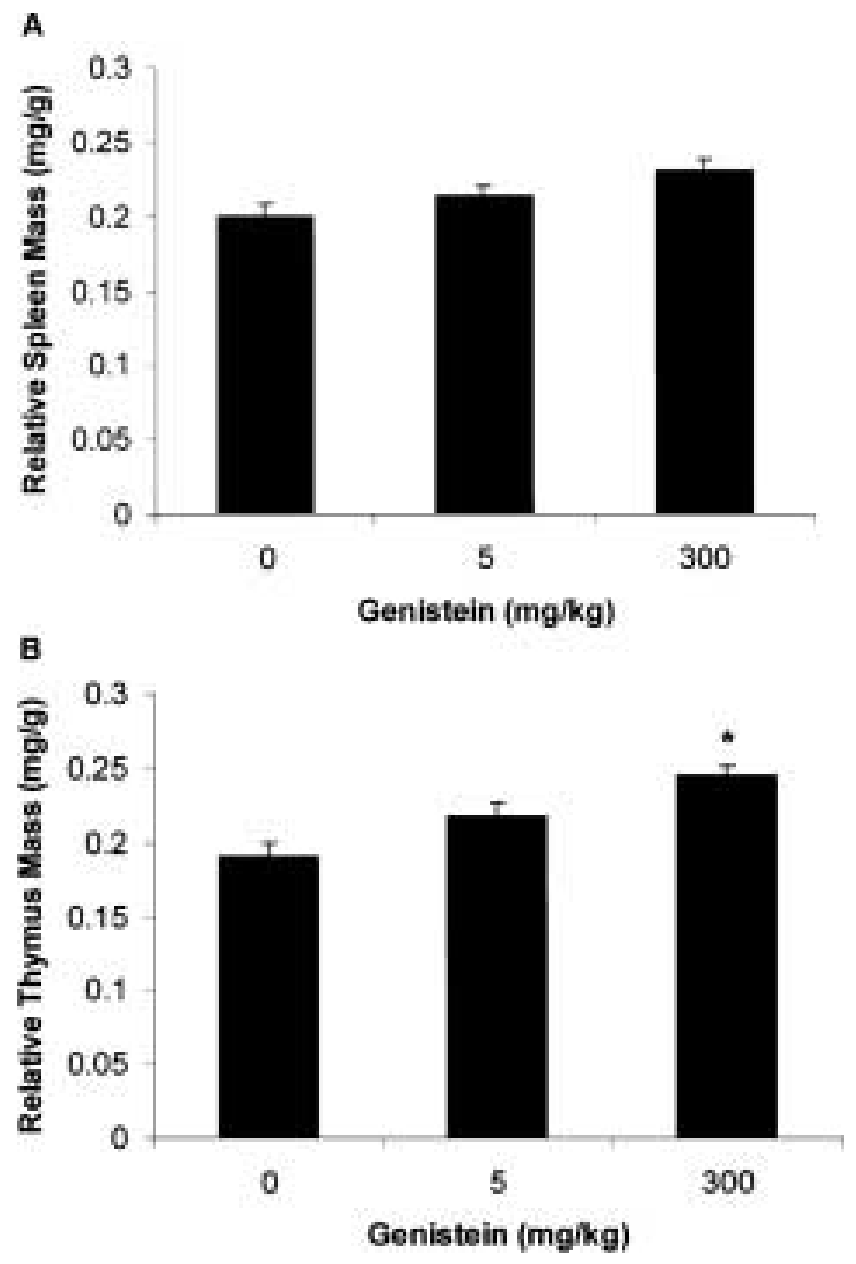

Fig. 1. Mean ( $\pm S E M)$ relative (A) spleen and (B) thymus masses ( $\mathrm{mg} / \mathrm{g}$ of body mass) from male offspring exposed to no $(n=6)$, low $(n=12)$, or high $(n=12)$ genistein diets. An asterisks $(*)$ indicates that males exposed to the high genistein diet have greater masses than male exposed to the genistein-free diet $(p<0.05)$.
$\mathrm{CD}^{+} \mathrm{T}$ cells in the spleen was significantly higher among males exposed to the high genistein diet than among males exposed to no genistein $(F(2,27)=$ 3.35, $p<0.05$; Table 1$)$. The total number of $\mathrm{T}$ cells in the spleen (percentages of $\mathrm{CD}^{+}$plus percentages of $\mathrm{CD}^{+} \mathrm{T}$ cells) was significantly higher in males exposed to genistein (both high and low doses) than in males not exposed to genistein $(F(2,27)=5.69$, $p<0.05$; Table 1). The percentage of $\mathrm{B}$ cells in the spleen was not affected by exposure to genistein $(p>0.05$; Table 1).

In the thymus, percentages of $\mathrm{CD} 4^{+} \mathrm{CD} 8^{-}$and $\mathrm{CD}^{-} \mathrm{CD}^{+} \mathrm{T}$ cells were not affected by exposure to genistein $(p>0.05$; Table 1). Percentages of doublepositive $\mathrm{CD}^{+} \mathrm{CD}^{+} \mathrm{T}$ cells in the thymus were significantly higher, whereas percentages of doublenegative $\mathrm{CD}^{-} \mathrm{CD}^{-} \mathrm{T}$ cells in the thymus were significantly lower among males exposed to the genistein diets compared with males not exposed to genistein $(F(2,27)=3.47, p<0.05, F(2,27)=4.44$, $p<0.05$, respectively; Table 1$)$.

\section{Cytokine Concentrations Are Not Affected by Genistein Exposure}

Synthesis of IL- 4 by splenocytes and thymocytes did not differ among males exposed to no (spleen: $12.1 \pm 2.0 \mathrm{pg} / \mathrm{ml}$; thymus: $11.4 \pm 1.9 \mathrm{pg} / \mathrm{ml})$, low (spleen: $14.1 \pm 1.7 \mathrm{pg} / \mathrm{ml}$; thymus: $10.5 \pm 0.8 \mathrm{pg} / \mathrm{ml}$ ), or high (spleen: $12.3 \pm 1.1 \mathrm{pg} / \mathrm{ml}$; thymus: $10.2 \pm$ $0.6 \mathrm{pg} / \mathrm{ml})$ genistein diets $(p>0.05$ in each case). Splenic and thymic production of IFN- $\gamma$ was marginally higher in males exposed to the low and high genistein diets compared with males that received no genistein $(F(2,27)=2.52, p=0.09$ and $F(2,27)=$ 2.76, $p=0.08$, respectively; Figs. $2 \mathrm{~A}$ and $2 \mathrm{~B}$ ).

\section{Testosterone Concentrations Are Reduced by Genistein Exposure}

Testosterone concentrations were significantly lower among males exposed to the low and high genistein diets as compared with males that received no genistein $(F(2,27)=4.93, p<0.05$; Fig. 3). Males with lower testosterone concentrations had higher percentages of double-positive $\mathrm{CD} 4^{+} \mathrm{CD} 8^{+} \mathrm{T}$ cells in the thymus than males with higher testosterone concentrations $(r=-0.42, p<0.05)$. In contrast, males with lower testosterone concentrations had lower percentages of $\mathrm{CD}^{+} \mathrm{CD}^{-}(r=0.37, p<0.05)$ and double-negative $\mathrm{CD}^{-} \mathrm{CD}^{-}(r=0.36, p<0.05)$ $T$ cells in the thymus than males with higher testosterone concentrations. There were no correlations among testosterone and organ masses, percentages of lymphocyte subpopulations in the spleen, or cytokine concentrations ( $p>0.05$ in each case).

\section{Discussion}

Although the effects of endogenous estrogens on immune function are well established, few studies have examined the hormonal effects of plant-derived 
Table 1. Mean percentage ( \pm SEM) of lymphocyte subpopulations in spleen and thymic tissue from male rats exposed to no $(0 \mathrm{mg} / \mathrm{kg}$ feed; $n=6)$, low $(5 \mathrm{mg} / \mathrm{kg}$ feed; $n=12)$, or high $(300 \mathrm{mg} / \mathrm{kg}$ feed; $n=12)$ genistein diets

Genistein (mg/kg of diet)

\begin{tabular}{lll}
\hline 0 & 300
\end{tabular}

$\begin{array}{ll}\text { Spleen } & \\ \text { CD } 4^{+} \mathrm{T} \text { cells } & 22.54 \pm 0.73 \\ \text { CD8 }{ }^{+} \mathrm{T} \text { cells } & 19.38 \pm 1.96 \\ \text { Total T cells } & 41.92 \pm 2.21 \\ \text { CD } 45 \mathrm{R} \text { B cells } & 50.22 \pm 1.05 \\ \text { Thymus } & \\ \mathrm{CD}^{-} \mathrm{CD} 8^{-} \mathrm{T} \text { cells } & 10.52 \pm 3.58 \\ \mathrm{CD}^{+} \mathrm{CD} 8^{-} \mathrm{T} \text { cells } & 7.478 \pm 1.830 \\ \mathrm{CD}^{-} \mathrm{CD} 8^{+} \mathrm{T} \text { cells } & 6.363 \pm 1.730 \\ \mathrm{CD}^{+} \mathrm{CD} 8^{+} \mathrm{T} \text { cells } & 75.63 \pm 7.02\end{array}$

$24.23 \pm 0.79$
$22.87 \pm 0.78$
$47.10 \pm 1.13^{*}$
$50.43 \pm 1.51$
$4.281 \pm 0.910^{*}$
$5.287 \pm 0.380$
$5.038 \pm 0.430$
$85.13 \pm 0.81^{*}$

$25.37 \pm 0.62$

$23.44 \pm 0.80 *$

$48.81 \pm 1.01^{*}$

$47.16 \pm 1.45$

$4.083 \pm 0.82 *$

$5.383 \pm 0.230$

$5.642 \pm 0.420$

$84.82 \pm 0.69 *$

Data represent the percentage of lymphocytes expressing the various cell surface markers. For each dependent measure, an asterisks $(*)$ indicates that males exposed to genistein are significantly different from genistein-free males based on a one-way ANOVA, $p<0.05$.

${ }^{\ddagger}$ Total $\mathrm{T}$ cells in the spleen $=$ the percentage of $\mathrm{CD}^{+} \mathrm{T}$ cells + the percentage of $\mathrm{CD}^{+} \mathrm{T}$ cells.

estrogens on the immune system. Additionally, the effects of phytoestrogen exposure on immune function may differ depending on whether animals are exposed as infants or as adults (11). In the present study, extending genistein exposure past weaning had no additional effect over perinatal exposure alone on endocrine or immune responses in adulthood. Males exposed to genistein early during development had heavier thymus masses, a higher percentage of $\mathrm{CD}^{+} \mathrm{T}$ cells in the spleen, more total $\mathrm{T}$ cells in the spleen, a reduced percentage of $\mathrm{CD}^{-} \mathrm{CD} 8^{-}$thymocytes, more double-positive $\mathrm{CD} 4^{+} \mathrm{CD}^{+} \mathrm{T}$ cells in the thymus, and marginally higher concentrations of IFN- $\gamma$ in both the spleen and thymus than genisteinfree males. Males exposed to genistein also had lower testosterone concentrations than males not exposed to genistein. Thus, these data illustrate that exposure to genistein during the sensitive period of sex differentiation affects both the endocrine and immune systems of males.

Testosterone concentrations were lower among males exposed to genistein. Males with lower testosterone concentrations had higher $\mathrm{CD} 4^{+} \mathrm{CD} 8^{+}$ T-cell numbers than males with higher testosterone concentrations. Generally, testosterone is considered immunosuppressive and is thought to underlie increased infection rates and reduced susceptibility to autoimmune diseases in males compared with females $(1,2,36)$. Castrated male rodents, male rodents that possess defective androgen receptors (i.e., the testicular feminization mouse model [Tfm]), and male rodents that do not produce sex steroids (i.e., hypogonadal mice) have enlarged thymus glands and elevated $\mathrm{B}$ cell production (36-38). Similar to males with gonadal dysfunctional, males exposed to the high dose of genistein had larger thymus glands than males not exposed to genistein.

In the present study, the enlarged thymus glands and increased percentage of double-positive $\mathrm{CD}^{+}$ $\mathrm{CD8}^{+} \mathrm{T}$ cells in the thymuses of males exposed to dietary genistein may be indicative of the suppressive effects of genistein on testosterone. Although percentages of $\mathrm{CD}^{+} \mathrm{CD}^{+} \mathrm{T}$ cells in the thymus were negatively correlated with testosterone concentrations, when $\mathrm{CD}^{+} \mathrm{CD}^{-}$(double stained) cells were examined, males with lower testosterone concentrations had lower cell counts. Studies examining the effects of genistein on immune function in castrated and intact males and females are required to determine whether genistein affects immune function directly or via changes in testosterone concentrations.

Genistein administered to adult gonadectomized male and female mice decreases numbers of $\mathrm{CD} 4^{+}$ $\mathrm{CD}^{-}$and $\mathrm{CD}^{+}{ }^{+} \mathrm{CD} 8^{+}$thymocytes (22). If estrogen receptors (both $\alpha$ and $\beta$ ) are blocked using fulvestrant, then the effects of genistein on the immune system are only partially reversed, illustrating that genistein can affect the immune system through sex steroidindependent mechanisms (22). Whether genistein affects the affinity or distribution of sex steroid receptors, including androgen receptors or steroid receptor coactivators (39) in immune cells should be examined.

The increased number of double-positive T cells (immature thymocytes) in genistein-exposed males may be beneficial because, following selection processes in the thymus, these cells mature into either $\mathrm{CD}^{+}$or $\mathrm{CD}^{+} \mathrm{T}$ cells and migrate to secondary lymphoid organs, such as the spleen. Although exposure to genistein had no effect on the numbers of B cells or $\mathrm{CD}^{+}{ }^{+} \mathrm{T}$ cells, genistein significantly increased the number of $\mathrm{CD}^{+}$splenocytes. B-cells, 


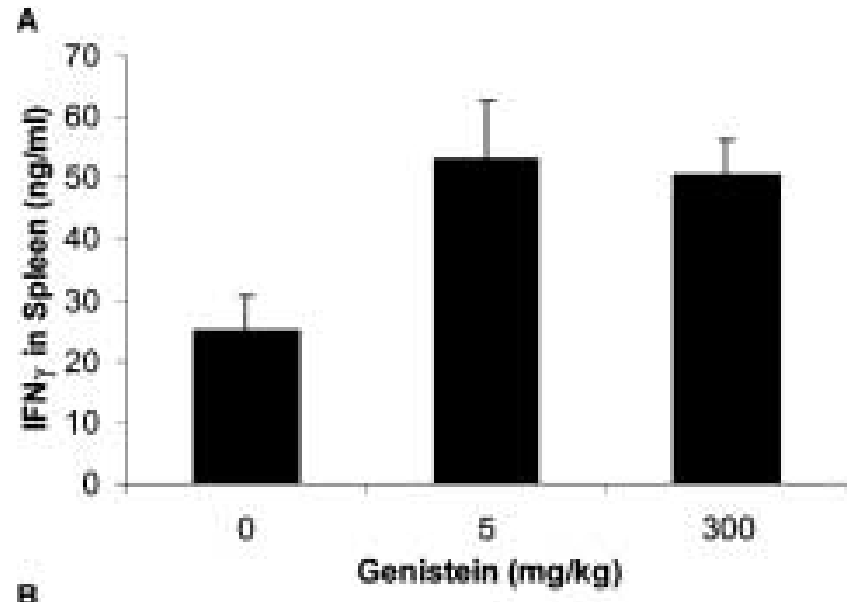

B

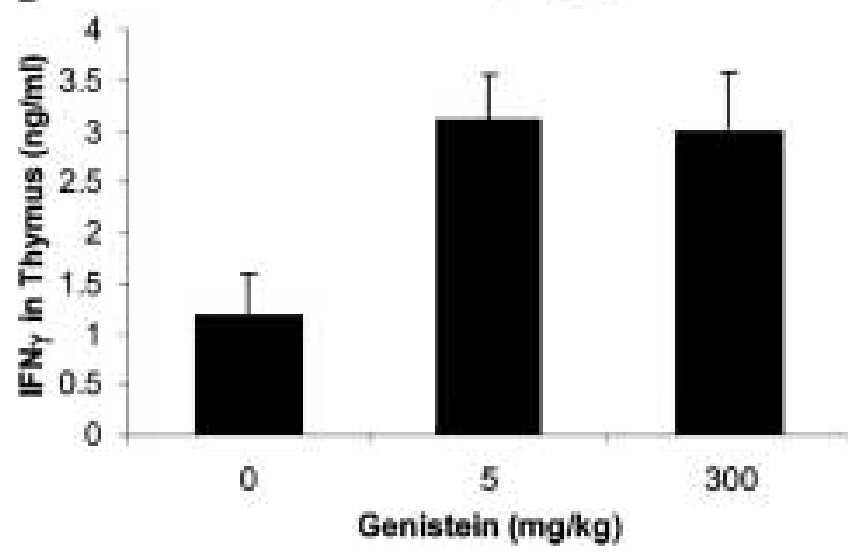

Fig. 2. Con A-stimulated mean ( \pm SEM) concentrations of IFN- $\gamma(\mathrm{ng} / \mathrm{ml})$ from (A) splenocytes and (B) thymocytes collected from males exposed to no $(n=6)$, low $(n=12)$, or high $(n=12)$ genistein diets.

with the help of $\mathrm{CD}^{+} \mathrm{T}$ cells, produce antibodies and form the cornerstone of humoral immunity. The data from the present study suggest that humoral immunity may not be affected by early genistein exposure in males. Because changes in numbers of immune cells do not necessarily equate with functional differences, future studies should examine the effects of early genistein exposure on antibody responses to microbial (infectious) and self- (autoimmune) antigens.

To date, the effects of phytoestrogens on cytokine production and release have not been reported. Helper $\mathrm{T}$ cells are functionally and phenotypically heterogeneous and can be differentiated based on the cytokines they release. In the present study, although the overall percentage of helper $\left(\mathrm{CD}^{+}\right)$ $\mathrm{T}$ cells was not altered by genistein, genisteinexposed males had marginally higher IFN- $\gamma$ concentrations (a Thl response) than males not exposed to genistein. IL-4 concentrations (a Th2 response) did not differ between males exposed to genistein and those not exposed. Dietary genistein exposure increased the proportion of cytotoxic $\left(\mathrm{CDB}^{+}\right) \mathrm{T}$ cells and the overall percentage of total $\mathrm{T}$ cells in the

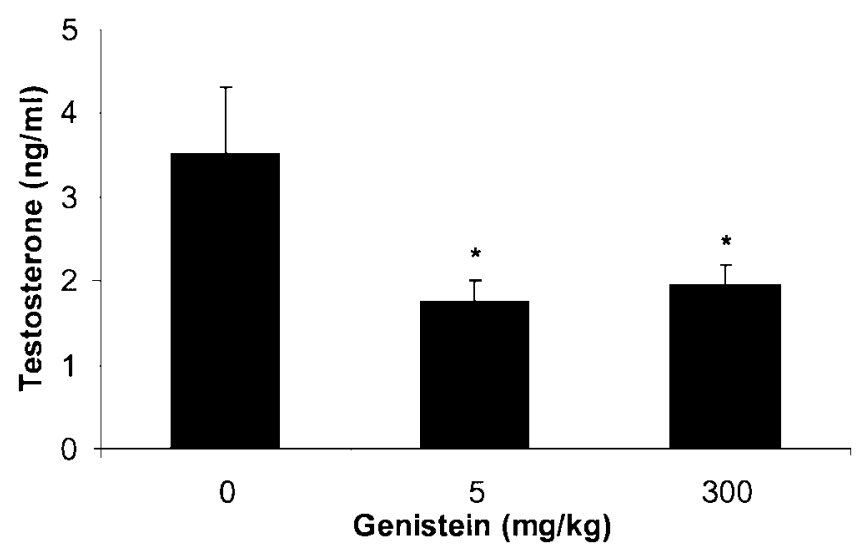

Fig. 3. Mean ( $\pm S E M)$ plasma concentrations of testosterone $(\mathrm{ng} / \mathrm{ml})$ from male rats exposed to no $(n=6)$, low $(n=12)$, or high $(n=12)$ genistein diets. An asterisks $(*)$ indicates that males exposed to both the high and low genistein diets have lower testosterone concentrations than males exposed to the genistein-free diet $(p<0.05)$.

spleen suggesting that cell-mediated immunity is enhanced by perinatal genistein exposure. Because cell-mediated immune responses are instrumental for fighting infection and suppressing tumor growth, these data imply that exposure to genistein may reduce susceptibility to certain diseases. In contrast to our study, adult exposure to genistein in gonadectomized mice reduces the proportion of $\mathrm{CD} 4^{+}$ $\mathrm{T}$ cells in both the thymus and spleen as well as the percentage of $\mathrm{CD}^{+}$splenocytes (22). Thus, phytoestrogens may exert differential effects depending on gonadal status and the timing of exposure.

In the present study, extending genistein exposure past weaning did not affect organ masses, lymphocyte subpopulations (percentages of the total lymphocyte population), cytokine production, or hormone concentrations. These data suggest that adult exposure to genistein is not required to permanently alter endocrine or immune responses in males. The critical period of exposure to genistein appears to occur during prenatal and neonatal development. These data are reminiscent of the effects of neonatal exposure to sex steroids on play behavior in rodents (40) and suggest that early exposure to genistein may have organizational effects on the endocrine and immune systems later in life.

To determine the overall impact of genistein on physiology, examination of the effects of endocrine disrupters on multiple biological systems is required. Although perinatal exposure to genistein appears to have beneficial effects on the immune system, studies conducted by our laboratory and others reveal that perinatal exposure to phytoestrogens has detrimental effects on reproductive physiology and behavior in male offspring (10-13,24, $33,41)$. In addition to lower testosterone concentrations, males exposed to genistein perinatally have reduced anogenital distance, delayed pubertal development, and reduced mating behavior as 
adults (i.e., ejaculations) compared with males not exposed to genistein (33). Because testosterone supports male-typic reproductive development and behavior and suppresses immune function, we hypothesize that suppression of testosterone underlies the demasculinizing effects of genistein on both the reproductive and immune systems. Future studies should continue to examine the effects of genistein on the dynamic relationship that exists among hormones, reproduction, and immune function in both males and females.

In summary, the data from the present study illustrate that exposure to phytoestrogens during early development has lasting effects on the endocrine and immune systems of male offspring. In the present study, the effects of genistein were more pronounced on cell-mediated than on humoral immune responses. Soy proteins are immunomodulatory and their effects during pregnancy or lactation require additional investigation. Presumably, enhanced immune responses may underlie some of the beneficial health-related outcomes associated with phytoestrogen consumption, including decreased incidences of breast and prostate cancer (42). Whether perinatal exposure to phytoestrogens affects susceptibility to diseases caused by infectious pathogens or autoimmune disorders requires investigation (42).

\section{Acknowledgments}

We thank Amy Cernetich, Bradley Register, Richa Verma, and Brandon Zonker for assistance with data collection and Dr Ann Lawler for assistance with the radioimmunoassays. We also thank Randy Nelson for helpful comments on an earlier draft of this manuscript. This research was supported by NIH AI 10324 (SLK), NIH HD 08544 (ABW), NASA grant NCC5305 (GEG), and in part by NIH grant P30 HD 06268.

\section{References}

1. Klein SL. (2000) The effects of hormones on sex differences in infection: from genes to behavior. Neurosci. Biobehav. Rev. 24: 627-638.

2. Olsen NJ, Kovacs WJ. (1996) Gonadal steroids and immunity. Endo. Rev. 17: 369-384.

3. Roberts CW, Walker W, Alexander J. (2001) Sex-associated hormones and immunity to protozoan parasites. Clin. Microbiol. Rev. 14: 476-488.

4. Luster MI, Hayes HT, Korach K, et al. (1984) Estrogen immunosuppression is regulated through estrogenic responses in the thymus. J. Immunol. 133: 110-116.

5. Spellberg B, Edwards JE. (2001) Type 1/type 2 immunity in infectious diseases. Clin. Infect. Dis. 32: 76-102.

6. Sorachi K, Kumagai S, Sugita M, Yodoi J, Imura H. (1993) Enhancing effect of 17 beta-estradiol on human NK cell activity. Immunol. Lett. 36: 31-35.

7. Karpuzoglu-Sahin E, Zhi-Jun Y, Lengi A, Sriranganathan N, Ansar Ahmed S. (2001) Effects of long-term estrogen treatment on IFN- $\gamma$, IL-2, and IL-4 gene expression and protein synthesis in spleen and thymus of normal C57BL/6 mice. $\mathrm{Cy}$ tokine 14: 208-217.

8. Lombardi G, Zarrilli S, Colao A, et al. (2001) Estrogens and health in males. Mol. Cell. Endocrinol. 178: 51-55.
9. Erlandsson MC, Ohlsson C, Gustafsson J-Å, Carlsten H. (2001) Role of oestrogen receptors $\alpha$ and $\beta$ in immune organ development and in oestrogen-mediated effects on thymus. Immunology 103: 17-25.

10. Colborn T. (1995) Environmental estrogens: health implications for humans and wildlife. Environ. Health Perspect. 103: 135-136.

11. Guillette LJ, Crain DA, Rooney AA, Pickford DB. (1995) Organization versus activation: the role of endocrine-disrupting contaminants (EDCs) during embryonic development in wildlife. Environ. Health Perspect. 103: 157-164.

12. Palanza P, Morellini F, Parmigiani S, vom Saal FS. (1999) Prenatal exposure to endocrine disrupting chemicals: effects on behavioral development. Neurosci. Biobehav. Rev. 23: 1011-1027.

13. Whitten PL, Naftolin F. (1998) Reproductive actions of phytoestrogens. Baillieres. Clin. Endocrinol. Metab. 12: 667-690.

14. Casanova M, You L, Gaido KW, Archibeque-Engle S, Janszen DB, d'A, Heck H. (1999) Developmental effects of dietary phytoestrogens in Sprague-Dawley rats and interactions of genistein and daidzein with rat estrogen receptors $\alpha$ and $\beta$ in vitro. Toxicol. Sci. 51: 236-244.

15. Akiyama T, Ishida J, Nakagawa $S$, Ogawara $H$, Watanabe $S$, Itoh N, Shibuya M, Fukami Y. (1987) Genistein, a specific inhibitor of tyrosine-specific protein kinases. J. Biol. Chem. 262: 5592-5595.

16. Park JB. (1999) Flavonoids are potential inhibitors of glucose uptake in U937 cells. Biochem. Biophys. Res. Commun. 260: 568-574.

17. Committee on Hormonally Active Agents in the Environment. (1999) Immunological effects. In: Hormonally active agents in the environment. Washington D.C.: National Academy Press, p. 186-209.

18. Jontell M, Hanks CT, Bratel J, Bergenholtz G. (1995) Effects of unpolymerized resin components on the function of accessory cells derived from the rat incisor pulp. J. Dent. Res. 74: 1162-1167.

19. Segura JJ, Jimenez-Rubio A, Pulgar R, Olea N, Guerrero JM, Calvo JR. (1999) In vitro effect of the resin component bisphenol A on substrate adherence capacity of macrophages. J. Endod. 25: 341-344.

20. Karpuzoglu-Sahin E, Hissong BD, Ansar Ahmed S. (2001) Interferon- $\gamma$ levels are upregulated by $17-\beta$-estradiol and diethylstilbestrol. J. Reprod. Immunol. 52: 113-127.

21. Weisglas-Kuperus N, Sas TCJ, Koopman-Esseboom C, van der Zwan CW, de Ridder MAJ, Beishuizen A, Hooijkaas H, Sauer PJJ. (1995) Immunological effects of background prenatal and postnatal exposure to dioxins and polychlorinated biphenyls in Dutch infants. Pediatr. Res. 38: 404-410.

22. Yellayi S, Naaz A, Szewczykowski MA, et al. (2002) The phytoestrogen genistein induces thymic and immune changes: a human health concern? Proc. Natl. Acad. Sci. 99: 7616-7621.

23. Reinli K, Block G. (1996) Phytoestrogen content of foods-a compendium of literature values. Nutr. Cancer 26: 123-148.

24. Martin JT. (2000) Sexual dimorphism in immune function: the role of prenatal exposure to androgens and estrogens. Eur. J. Pharmacol. 405: 251-261.

25. Guo TL, McCay JA, Zhang LX, Brown RD, You L, Karrow NA, Germolec DR, White KL. (2001) Genistein modulates immune responses and increases host resistance to $\mathrm{B} 16 \mathrm{~F} 10$ tumor in adult female B6C3F1 mice. Nutr. Immunol. 131: 3251-3258.

26. Ishimi Y, Miyaura C, Ohmura M, et al. (1999) Selective effects of genistein, a soybean isoflavone, on B-lymphopoiesis and bone loss caused by estrogen deficiency. Endocrinology 140: 1893-1900.

27. Awoniyi CA, Roberts D, Veeramachaneni DNR, Hurst BS, Tucker KE, Schlaff WD. (1998) Reproductive sequelae in female rats after in utero and neonatal exposure to the phytoestrogen genistein. Fertil. Steril. 70: 440-447.

28. Flynn KM, Ferguson SA, Delclos KB, Newbold RR. (2000) Effects of genistein exposure on sexually dimorphic behaviors in rats. Toxicol. Sci. 55: 311-319. 
29. Roberts D, Veeramachaneni DNR, Schlaff WD, Awoniyi CA. (2000) Effects of chronic dietary exposure to genistein, a phytoestrogen during various stages of development on reproductive hormones and spermatogenesis in rats. Endocrine 13: $281-286$.

30. Strauss L, MäKelä S, Joshi S, Huhtaniemi I, Santti R. (1998) Genistein exerts estrogen-like effects in male mouse reproductive tract. Mol. Cell. Endocrinol. 144: 83-93.

31. Nilsson R. (2000) Endocrine modulators in the food chain and environment. Toxicol. Pathol. 28: 420-431.

32. Holson RR, Pearce B. (1992) Principles and pitfalls in the analysis of prenatal treatment effects in multiparous species. Nerotoxicol. Teratol. 14: 221-228.

33. Wisniewski AB, Klein SL, Lakshmanan Y, Gearhart JP. Exposure to genistein during gestation and lactation demasculinizes the reproductive system in rats. J. Urol. (in press).

34. Coward L, Barnes NC, Setchell KDR, Barnes S. (1993) Genistein, daidzein, and their $\beta$-glycoside conjugates: antitumor isoflavones in soy-bean foods from American and Asian diets. J. Agric. Food Chem. 41: 1961-1967.

35. Klein SL, Bird BH, Glass GE. (2001) Sex differences in immune responses and viral shedding following Seoul virus infection in Norway rats. Am. J. Trop. Med. Hyg. 65: 57-63.
36. Smithson G, Couse JF, Lubahn DB, Korach KS, Kincade PW. (1998) The role of estrogen receptors and androgen receptors in sex steroid regulation of B lymphopoiesis. J. Immunol. 161: 27-34.

37. Olsen NJ, Kovacs WJ. (2001) Effects of androgens on T and B lymphocyte development. Immunol. Res. 23: 281-288.

38. Smithson G, Beamer WG, Shultz KL, Christianson SW, Shultz LD, Kincade PW. (1994) Increased B lymphopoiesis in genetically sex steroid-deficient hypogonadal (hpg) mice. J. Exp. Med. 1: 717-720.

39. Auger AP, Tetel MJ, McCarthy MM. (2000) Steroid receptor coactivator-1 (SRC-1) mediates the development of sexspecific brain morphology and behavior. Proc. Natl. Acad. Sci. 97: 7551-7555.

40. Meaney MJ, Stewart J. (1981) Neonatal-androgens influence the social play of prepubescent rats. Hormones and Behavior 15:197-213.

41. Gray LE, Ostby J. (1998) Effects of pesticides and toxic substances on behavioral and morphological reproductive development: endocrine versus nonendocrine mechanisms. Toxicol. Ind. Health 14: 159-184.

42. Ansar Ahmed S. (2000) The immune system as a potential target for environmental estrogens (endocrine disrupters): a new emerging field. Toxicology 150: 191-206. 